\title{
ISOLATION AND IDENTIFICATION OF PIGMENT PRODUCING BACTERIA FROM THE RATARGUL SWAMP FOREST SOIL
}

\author{
Nafisa Anzum, Farhana Islam Khan ${ }^{1}$, Mohammad Zabed Hossain, \\ Mohammad Nurul IsLam and MihIR Lal SAHA* \\ Department of Botany, University of Dhaka, Dhaka-1000, Bangladesh
}

Key words: Pigment producing bacteria, Ratargul Swamp Forest, Soil

\begin{abstract}
Pigments are one of the most significant secondary metabolites produced by microorganisms. The aim of the present study was to isolate and identify pigmentproducing bacteria from the Ratargul Swamp Forest (RSF) soil, which is the one and only fresh water swamp forest of Bangladesh. Soil samples were randomly collected from 10 different quadrates $(10 \mathrm{~m} \times 10 \mathrm{~m})$ of RSF. The $\mathrm{pH}$ values of the soil samples were found to be strongly acidic and ranged between 4.71 and 5.48. Bacterial load of the samples ranged from $1.33 \times 10^{5}$ to $1.93 \times 10^{8} \mathrm{cfu} / \mathrm{g}, 6.05 \times 10^{6}$ to $9.07 \times 10^{7} \mathrm{cfu} / \mathrm{g}$ and from $1.16 \times 10^{7}$ to $1.61 \times 10^{8} \mathrm{cfu} / \mathrm{g}$ on nutrient agar (NA), peptone yeast-extract glucose (PYG) agar and Luria-Bertani (LB) agar media, respectively. Interestingly, both the highest and lowest bacterial counts were observed on NA, which was $1.93 \times 10^{8} \mathrm{cfu} / \mathrm{g}$ and $1.33 \times 10^{5} \mathrm{cfu} / \mathrm{g}$, respectively. The isolates were found to produce various pigments like yellow, red, dark orange and sweet pink during their colony developments. A total of 71 bacterial isolates were obtained of which 11 were subjected to further study. All the selected bacteria were found to be rod shaped. Out of the 11 isolates, 9 were Gram-positive and 2 were Gramnegative. Provisionally identified potential pigment producing eight bacterial isolates were identified by using molecular marker. Seven of them were matched with their conventional identification up to generic level but conventionally identified Erwinia stewartii was found to be as Aeromonas sobria. Among the 11 isolates, 8 could produce three different types of pigments namely red, yellow and dark orange during in vitro pigment production. The isolated pigment producing bacteria could be used for better biotechnological application.
\end{abstract}

\section{Introduction}

Both natural pigments and synthetic dyes have been extensively used in various fields of everyday life such as food, feed, textile, paper, printing ink, cosmetic and pharmaceuticals. Since color is an important attribute that determines the consumer's acceptance of food, color additives are essential in food industry. As a result, various synthetic food colors have been manufactured but many of them encompass various hazardous effects. Due to the toxicity of several artificial colorants, uses of natural additives are of increasing interest. Increasing consumer's awareness put string emphasis on the production of colors or natural colors extracted from fruits, vegetables, roots and microorganisms ${ }^{(1)}$.

*Author for correspondence: <sahaml@du.ac.bd>. 1Present address: Department of Botany, Jagannath University, Dhaka-1100, Bangladesh. 
Microbial pigment production is a recent phenomenon. When the microbial cells are used to produce the color the term refers to 'microbial pigments' ${ }^{\text {(2) }}$. These are one of the most significant secondary metabolites produced by microorganisms. The main role of these pigments is to protect the bacterial cells against injurious rays of light. It also helps them in their photosynthetic activities and this has been observed specially in case of the members of cyanobacteria. Pigments produced from natural sources are of worldwide interest and is gaining significance. This type of pigment is highly productive because it is highly versatile and prolific over other sources. Cheap substrates can be used for bulk production of pigments even sometimes it can grow on waste products. Thus, it also recycles the waste of the environment ${ }^{(3)}$.

Bacterial fermentation is inherently faster and more productive compared to any other chemical process. Bacterial genes are easy to manipulate, easy for propagation and wide strain selection can also be done. So simple and fast culturing of bacterial cells allow continuous bioreactor operation that makes it more convenient for large scale production of pigments. Though microbial pigments are several times more expensive, they still can compete with synthetic dyes for being natural and safe. There is an increased push to reduce the production costs for microbial pigments by using low cost substrates or strain improvements, and in the near future, there may be a monopoly market for microbial pigments.

Textile industries remain the largest consumer of organic pigments and dyes, while faster growth is expected to occur in other industrial sector such as printing inks, paints, and coating agents ${ }^{(4)}$. Considering the increasing demand of microbial pigments and environmental hazards caused by synthetic colors, the present study was aimed to isolate and identify pigment producing bacteria from the Ratargul Swamp Forest soil.

\section{Materials and Methods}

Ten soil samples were randomly collected from ten different quadrates of Ratargul Swamp Forest (RSF). Samples were collected aseptically in sterile plastic bags. The samples were labeled properly and brought into the laboratory as soon as possible and $\mathrm{pH}$ was measured by a $\mathrm{pH}$ meter (ToA-DKK, HM-31P, Japan). Serial dilution technique ${ }^{(5)}$ was followed using nutrient agar (NA) ${ }^{(6)}$, peptone yeast extract glucose (PYG) $\operatorname{agar}^{(7)}$ and Luria-Bertani (LB) agar ${ }^{(7)}$ media for enumeration of aerobic heterotrophic bacteria associated with the collected RSF soil samples. Inoculated plates were inversely incubated at $37^{\circ} \mathrm{C}$ for $24 \mathrm{~h}$ in an incubator (Memmert $\mathrm{GmbH}+\mathrm{Co} \mathrm{Kg} 8540$ Schwabach, Germany) followed by seven days of refrigeration at $4^{\circ} \mathrm{C}$ for developing discrete pigmented bacterial colonies. Then, the colonies were counted, isolated and screened on the basis of visual estimation for further studies. The selected bacterial isolates were purified through streak plate technique (Fig. 1). Following standard manuals, Gram staining and essential biochemical tests were performed. Characterization and identification of the isolates were made through standard microbiological methods ${ }^{(8)}$.

Molecular identification of potential ten isolates was conducted by amplifying $\sim 600 \mathrm{bp}$ fragments of $16 \mathrm{~S}$ rDNA followed by sequence analysis using NCBI-BLAST search (Fig. 2). 
Amplification of DNA was done using the primer pair CC [F] 5'-CCAGACTCCTAC GGGA GGCAGC-3 ' and CD [R] 5'-CTTGTGCGGGCCCCCGTCAATTC- 3 ' designed by Rudi et al. ${ }^{(9)}$. Supernatant of heat-lysed cell suspension was used as the source of template DNA for PCR amplification. The amplified products were separated electrophoretically on $1 \%$ agarose gel. DNA bands were observed on UV-transilluminator and photographed by a gel documentation system (Microdoc DI-HD, MUV21-254/365, Cleaver Scientific, UK). Sequencing of DNA was performed in an automated gene sequencer and sequences were analyzed through NCBI-BLAST database (http://blast.ncbi.nlm.nih.gov/) and rRNA BLAST (http://bioinformatics.psb.ugent.be/ cgi-bin/rRNA/blastform.cgi) programs.
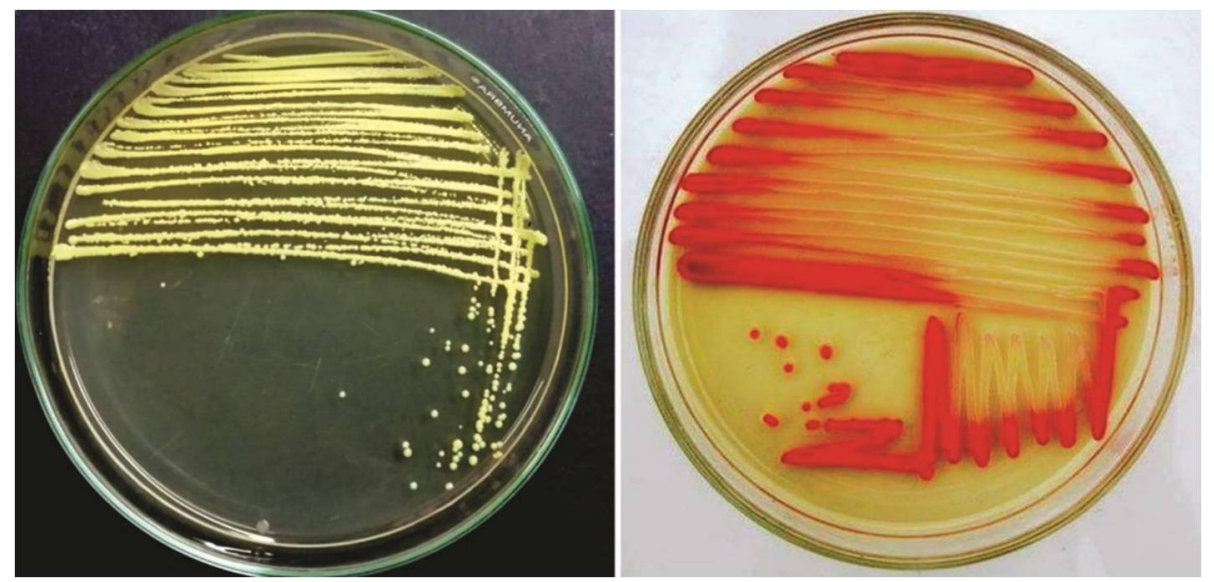

Fig. 1. Purification of pigmented bacterial isolate by streak dilution.

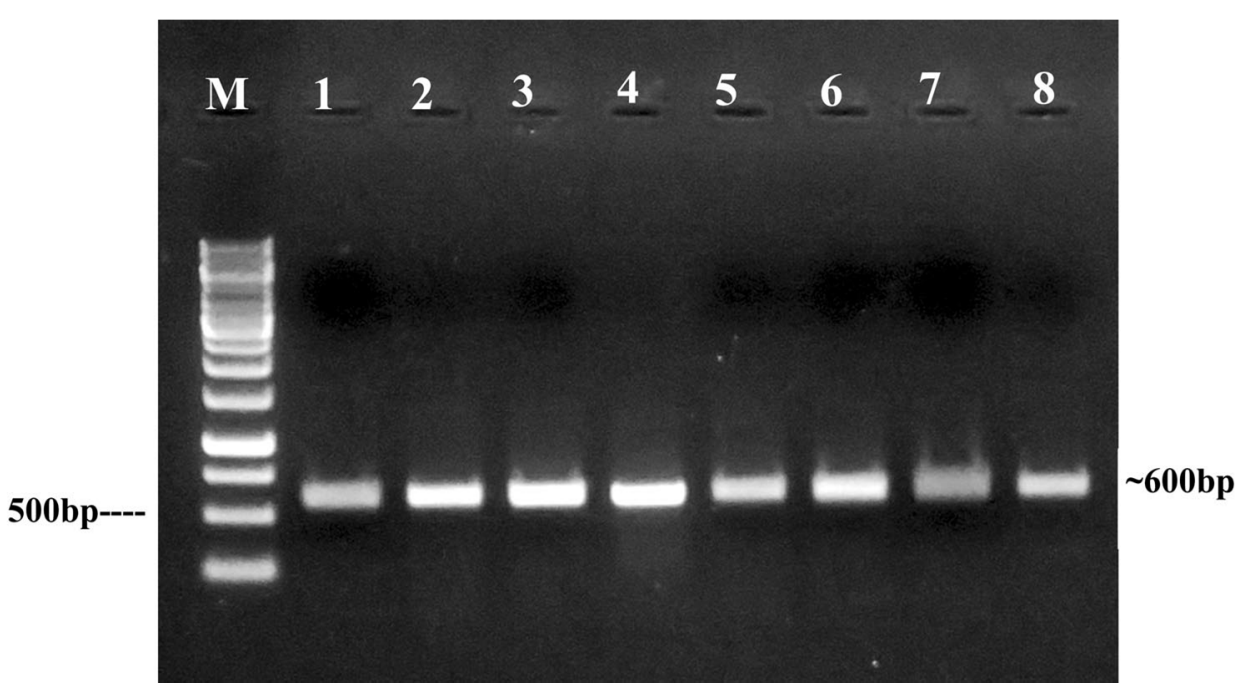

Fig. 2. PCR amplification of part of the $16 \mathrm{~S}$ rRNA gene. Lane $\mathrm{M}$ is the $1.0 \mathrm{~kb}$ ladder and lanes $1-8$ are representing 8 different bacterial isolates obtained from Ratargul Swamp Forest soil. 


\section{Results and Discussion}

A total of ten soil samples were randomly collected from ten different quadrates of Ratargul Soil Forest. The bacterial load of different samples was shown in Table 1. The heterotrophic bacterial load of the collected samples ranged in between $1.33 \times 10^{5}$ to $1.93 \times 10^{8} \mathrm{cfu} / \mathrm{g}, 6.05 \times 10^{6}$ to $9.07 \times 10^{7} \mathrm{cfu} / \mathrm{g}$ and $1.16 \times 10^{7}$ to $1.61 \times 10^{8} \mathrm{cfu} / \mathrm{g}$ on NA, PYG agar and LB agar media, respectively. Both the highest and lowest bacterial count was observed on NA which was $1.93 \times 10^{8} \mathrm{cfu} / \mathrm{g}$ (Quadrate 1) and $1.33 \times 10^{5} \mathrm{cfu} / \mathrm{g}$ (Quadrate 3), respectively. The difference in bacterial count might be due to the difference between the physical and chemical properties of soil and bioticabiotic stresses that might lead to pigment production of the bacteria present at that particular habitat as their defense mechanism. The indigenous organisms ecologically adapted to a particular habitat may be the cause of differences between isolated and referred organisms. In course of this adaptation their characteristics could be modified gradually ${ }^{(10)}$. The results revealed that pigment producing bacteria are randomly distributed in the soil in RSF.

Table 1. Heterotrophic bacterial load of the collected soil samples from the Ratargul Swamp Forest (RSF) soil.

\begin{tabular}{lccc}
\hline \multirow{2}{*}{$\begin{array}{l}\text { Quadrate }(\mathrm{Q}) \\
\text { No. }\end{array}$} & \multicolumn{3}{c}{ Bacterial load (cfu/g) on different media } \\
\cline { 2 - 4 } $\mathrm{Q}_{1}$ & $1.33 \times 10^{5}$ & $2.20 \times 10^{7}$ & LB agar \\
$\mathrm{Q}_{2}$ & $1.54 \times 10^{7}$ & $3.50 \times 10^{7}$ & $1.61 \times 10^{8}$ \\
$\mathrm{Q}_{3}$ & $\mathbf{1 . 9 3 \times 1 0 ^ { 8 }}$ & $1.57 \times 10^{7}$ & $1.41 \times 10^{7}$ \\
$\mathrm{Q}_{4}$ & $1.40 \times 10^{8}$ & $2.11 \times 10^{7}$ & $1.96 \times 10^{7}$ \\
$\mathrm{Q}_{5}$ & $9.92 \times 10^{7}$ & $5.23 \times 10^{7}$ & $2.19 \times 10^{7}$ \\
$\mathrm{Q}_{6}$ & $4.51 \times 10^{7}$ & $2.35 \times 10^{7}$ & $3.78 \times 10^{7}$ \\
$\mathrm{Q}_{7}$ & $3.34 \times 10^{7}$ & $9.07 \times 10^{7}$ & $1.37 \times 10^{7}$ \\
$\mathrm{Q}_{8}$ & $5.17 \times 10^{7}$ & $3.15 \times 10^{7}$ & $2.66 \times 10^{7}$ \\
$\mathrm{Q}_{9}$ & $5.23 \times 10^{7}$ & $1.22 \times 10^{7}$ & $1.16 \times 10^{7}$ \\
$\mathrm{Q}_{10}$ & $9.42 \times 10^{7}$ & $6.05 \times 10^{6}$ & $2.81 \times 10^{7}$ \\
Average & $\mathbf{1 . 4 0 \times 1 0 ^ { 8 }}$ & $\mathbf{3 . 1 0 \times 1 0 ^ { 7 }}$ & $\mathbf{3 . 4 6 \times 1 0 ^ { 7 }}$ \\
\hline
\end{tabular}

$\mathrm{NA}=$ Nutrient Agar, $\mathrm{PYG}=$ Peptone Yeast extract Glucose, $\mathrm{LB}=$ Luria-Bertani

All the vibrant pigment producing bacterial isolates were subjected to qualitative screening on the basis of visual estimation. During this study, 71 pigment-producing bacteria were isolated from the different samples and finally 11 isolates were selected for conventional identification. Out of 11 isolates, 9 were Gram-positive rods and 2 were Gram-negative rods. This was in accordance with the findings of other workers ${ }^{(11)}$ where they reported 4 Gram positive rod shaped pigment producing bacteria cultured from soil and air samples. 
Table 2. Major biochemical tests and provisional identification of Gram positive bacteria isolated from Ratargul Swamp Forest (RSF) soil.

\begin{tabular}{|c|c|c|c|c|c|c|c|c|}
\hline \multirow[t]{2}{*}{ Isolates } & \multicolumn{7}{|c|}{ Biochemical tests } & \multirow{2}{*}{$\begin{array}{l}\text { Provisional } \\
\text { Identification }\end{array}$} \\
\hline & Catalase & VP & Starch & Casein & Citrate & Propionate & Nitrate & \\
\hline $\mathrm{S} 1 / \mathrm{N} / 1$ & - & - & - & - & + & + & + & Bacillus megaterium \\
\hline $\mathrm{S} 2 / \mathrm{L} / 1$ & + & + & - & + & - & - & + & $\begin{array}{l}\text { Microbacterium } \\
\text { imperial }\end{array}$ \\
\hline $\mathrm{S} 2 / \mathrm{L} / 4$ & + & + & - & + & - & + & - & $\begin{array}{l}\text { Microbacterium } \\
\text { laevaniformans }\end{array}$ \\
\hline $\mathrm{S} 2 / \mathrm{L} / 3$ & + & + & - & + & - & - & - & $\begin{array}{l}\text { Microbacterium } \\
\text { imperial }\end{array}$ \\
\hline $\mathrm{S} 2 / \mathrm{L} / 7$ & + & + & - & + & - & + & - & $\begin{array}{l}\text { Microbacterium } \\
\text { laevaniformans }\end{array}$ \\
\hline $\mathrm{S} 3 / \mathrm{L} / 2$ & + & - & - & + & - & + & - & $\begin{array}{l}\text { Microbacterium } \\
\text { laevaniformans }\end{array}$ \\
\hline $\mathrm{S} 4 / \mathrm{P} / 3$ & - & - & & - & + & + & - & Bacillus megaterium \\
\hline $\mathrm{S} 5 / \mathrm{L} / 2$ & + & - & - & + & - & + & - & $\begin{array}{l}\text { Microbacterium } \\
\text { laevaniformans }\end{array}$ \\
\hline $\mathrm{S} 7 / \mathrm{N} / 3$ & - & - & - & + & + & + & + & Bacillus firmus \\
\hline
\end{tabular}

VP =Voges-Proskauer, '+' = positive result '-' = negative result

Table 3. Major biochemical tests and provisional identification of Gram negative bacteria isolated from Ratargul Swamp Forest (RSF) soil.

\begin{tabular}{lcccccccc}
\hline \multirow{3}{*}{ Isolates } & \multicolumn{9}{c}{ Biochemical tests } & \multicolumn{1}{c}{ Provisional Identification } \\
\cline { 2 - 7 } & Catalase & Oxidase & Urease & Indole & $\mathrm{H}_{2} \mathrm{~S}$ & Tyrosine & $\mathrm{KOH}$ & \\
\hline S2/L/6 & + & + & + & - & - & - & + & Serratia marcescens \\
S3/L/5 & + & - & + & - & - & - & + & Erwinia stewartii \\
\hline
\end{tabular}

'+'= positive result ' - ' $=$ negative result.

Results of some of the major biochemical tests for provisional identification are shown in Table 2 and 3. The isolated Gram-positive rods were provisionally identified as the different species of the two genera Microbacterium and Bacillus. In a recent study, Fatma et al. ${ }^{(12)}$ reported a novel antioxidant pigment produced by a photochromogenic Microbacterium oxydans FJM1. Carotenoid production by a novel isolate of Microbacterium paraoxydans also reported by others $^{(13)}$. In another study, Goswami and Bhowal ${ }^{(1)}$ reported red pigment production from a novel strain of Bacillus species. On the other hand, 2 Gram-negative isolates were identified as Serratia marcescens and Erwinia stewartii. Sinha et al. ${ }^{(3)}$ reported red and light orange pigment production by Serratia whereas Mohammadi et al. ${ }^{(14)}$ reported pigment production by Erwinia. 
Table 4. Molecular identification of some potential bacterial isolates from Ratargul Swamp Forest soil.

\begin{tabular}{llllll}
\hline Isolate No. & \multicolumn{5}{c}{ Molecular identification } \\
\cline { 2 - 5 } & Scientific name & Strain & $\begin{array}{l}\text { Max. } \\
\text { coverage score }\end{array}$ & E value & $\begin{array}{l}\text { Identity match } \\
(\%)\end{array}$ \\
\hline S2/L/1 & Microbacterium sp. & C-2 & 974 & 0.0 & $97.57 \%$ \\
& & PWB-7 & & & \\
S2/L/4 & Microbacterium oleivorans & MV-19 & 789 & 0.0 & $91.53 \%$ \\
S2/L/6 & Serratiasp. & Clone-48 & 1089 & $1 \mathrm{e}-23$ & $87.61 \%$ \\
S2/L/3 & Microbacterium sp. & HBUM & 989 & 0.0 & $98.08 \%$ \\
& & 178211 & & & \\
S2/L/7 & Microbacterium sp. & M 24 & 989 & 0.0 & $98.40 \%$ \\
S3/L/2 & Microbacterium oleivorans & MV 5 & 974 & 0.0 & $98.05 \%$ \\
S3/L/5 & Aeromonas sobria & SB 16 & 1343 & $3 \mathrm{e}-20$ & $97.01 \%$ \\
S5/L/2 & Microbacterium oleivorans & UAC-76 & 664 & 0.0 & $87.82 \%$ \\
\hline
\end{tabular}

Identification of 8 potential pigment producing isolates was further confirmed through molecular analysis based on 16S rRNA gene sequencing. Following BLAST search analysis of the obtained sequences the isolates were identified as Microbacterium sp. C-2 PWB-7, Microbacterium oleivorans MV-19, Serratia sp. clone-48, Microbacterium sp. HBUM 178211, Microbacterium sp. M24, Microbacterium oleivorans MV5, Aeromonas sobria SB16, Microbacterium oleivorans UAC-76 (Table 4).

Table 5. Comparison between provisional and molecular identification of eight isolates obtained from Ratargul Swamp Forest Soil.

\begin{tabular}{lll}
\hline Isolate No. & Provisional Identification & Molecular Identification \\
\hline S2/L/1 & Microbacterium imperiale & Microbacterium sp. C-2PWB-7 \\
S2/L/4 & Microbacterium laevaniformans & Microbacterium oleivorans MV-19 \\
S2/L/6 & Serratia marcescens & Serratia sp. Clone-48 \\
S2/L/3 & Microbacterium imperiale & Microbacterium sp. HBUM 178211 \\
S2/L/7 & Microbacterium laevaniformans & Microbacterium sp. M 24 \\
S3/L/2 & Microbacterium laevaniformans & Microbacterium oleivorans MV 5 \\
S3/L/5 & Erwinia stewartii & Aeromonas sobria SB 16 \\
S5/L/2 & Microbacterium laevaniformans & Microbacterium oleivorans UAC-76 \\
\hline
\end{tabular}

In this study, molecular identification of seven isolates were matched with their provisional identification up to generic level and only one isolate was found to be different. Comparison between provisional and molecular identification was shown in Table 5. Therefore, conventional identification of bacteria based on their morphology, physiological and biochemical profile was found to be valid to some extent in comparison to molecular identification. 
The present study was found to be effective for the isolation of the pigment producing bacteria from RSF soil. Now a day's researchers are focusing on bio-color producing microorganisms for replacing the demand of synthetic colors by it. The search for promising strains of pigment producers is a continuous process and development of efficient pigment producing bacteria is a prime need to control environmental hazards due to random use of synthetic nonbiodegradable dyes. Thus, the present study deals with an approach of developing new sources of bio-colors from easily cultivable indigenous soil bacterial species that can be further exploited at larger scale.

\section{Acknowledgements}

The first author of this research work is grateful to the Ministry of Science and Technology, Govt. of the People's Republic of Bangladesh for providing partial financial support for this research work through National Science \& Technology Fellowship program and also thanks to Ecology \& Environment Laboratory of the Department of Botany, University of Dhaka for their cordial help during sampling and Plant Tissue Culture and Biotechnology Laboratory of the same Department for helping during molecular identification of the isolates. The authors are also grateful to Centre for Advanced Research in Sciences (CARS), University of Dhaka for providing sequencing facilities.

\section{References}

1. Goswami B and $\mathbf{J}$ Bhowal 2014. Identification and characterization of extracellular red pigment producing bacteria isolated from soil. Int. J. Curr. Microbiol. App. Sci. 3(9): 169-176.

2. Masi C, V Duraipandi, D Yuvaraj, P Vivek and N Parthasarathy 2014. Production and extraction of bacterial pigments from novel strains and their applications. Res. J. Pharm. Bio. Chem. Sci. 5(6): 584-593.

3. Sinha S, S Choubey, A Kumar and P Bhosale 2017. Identification, characterization of pigment producing bacteria from soil and water and testing of antimicrobial activity of bacterial pigments. Int. J. Pharm. Sci. 42(2): 119-124.

4. Usman MH, N Abdulkadir, M Gani and MH Maiturare 2017. Bacterial pigments and its significance. MOJ Bioequiv Availab. 4(3): 285-288.

5. Greenberg AE, JJ Connors, D Jenkins and MAH Franson1998. Standard methods for examination of water and wastewater ( $20^{\text {th }}$ ed.). APHA, Washington DC. pp. 756.

6. Eklund C and CE Lankford 1967. Laboratory manual for general microbiology. Prentice-Hall International Inc. London. pp. 299.

7. Atlas RM 1997. Handbook of microbiological media ( $2^{\text {nd }}$ ed.). CRC Press. NY. pp. 1706.

8. Sneath PHA, MES Mair and JG Holt 1986. Bergey's manual of systematic bacteriology $\left(9^{\text {th }}\right.$ ed.). Williams and Wilkins Company, Baltimore. USA. pp.1120-1125.

9. Rudi K, OM Skulberg, F Larsenand KS Jakobsen1997. Strain characterization and classification of oxyphotobacteria in clone cultures on the basis of $16 \mathrm{~S}$ rRNA sequences from the variable regions V6, V7 and V8. App. Environ. Microbiol. 63: 2593-2599. 
10. Bruke V 1934. The interchange of bacteria between the fresh water and sea. J. Bact. 27: 201-205.

11. Sasidharan P, R Raja, C Karthik, S Ranandkumar and AP Indra2013. Isolation and characterization of yellow pigment producing Exiguobacterium sps. J. Biochem. Toxic. 4(4): 632-635.

12. Fatma MM, KM Jessica, B Jodrey, D Benoit and B Marc 2016. Structural characterization of a novel antioxidant pigment produced by a photochromogenic Microbacterium oxydans strain. Appl. Biochem. Biotechnol. 180(7): 1286-1300.

13. Swati O, K Sumeet and M Saroj 2017. Carotenoid production by a novel isolate of Microbacterium paraoxydans. Indian J. Microbiol. 58(1): 118-122.

14. Mohammadi M, L Burbank and MC Roper 2012. Biological role of pigment production for the bacterial phytopathogen Pantoea stewartii subsp. stewartii. Appl. Environ. Microbiol. 78(19): 6859-6865.

(Manuscript received on 5 May, 2021; accepted on 25 November, 2021) 